\title{
Legalitas Bitcoin Dalam Transaksi Bisnis Di Indonesia
}

\author{
Raden Muhammad Arvy Ilyasa \\ Mahasiswa Fakultas Hukum, Universitas Negeri Semarang \\ Semarang, Indonesia \\ Surel: rmuhammadarvy123@gmail.com
}

\begin{abstract}
ABSTRAK
Dunia saat ini sedang menghadapi fenomena disrupsi, dimana pergerakan dunia industri bergerak sangat cepat dari tatanan lama menuju tatanan yang baru. Dalam perkembangan di bidang ekonomi pada era ini sejalan dengan perkembangan teknologi, dan salah satu perkembangan di bidang ekonomi adalah munculnya Bitcoin. Bitcoin adalah uang virtual yang menggunakan teknologi Cryptocurrency, sebagai salah satu uang virtual yang terkenal menjadi tren baru sebagai pembayaran internasional dengan semua manfaatnya. Di antara Cryptocurrency yang ada yang paling menonjol adalah Bitcoin. Di Indonesia, Bitcoin telah menarik perhatian dikarenakan beberapa kelebihan yang dimilikinya serta sudah mulai melakukan ekspansi besar dan sudah tersedia marketplace tersendiri. Dalam peredarannya di Indonesia Bitcoin menjadi polemik tersendiri di dunia maupun Indonesia. Ada beberapa negara di dunia yang melegalkan peredaran Bitcoin serta memiliki regulasi hukum dan juga ada negara yang melarang keras peredarannya. Di Indonesia sendiri belum ada kejelasan apakah Bitcoin boleh digunakan atau tidak sebagai suatu mata uang, serta sikap pemerintah yang menyatakan bahwa segala resiko penggunaan Bitcoin ditanggung oleh pemilik dan penggunaan Bitcoin di Indonesia yang justru bertentangan dengan pasal 28 UUD 1945 yang menyatakan bahwa negara harus menjamin kepastian hukum dan perlindungan hukum bagi setiap warga negaranya.
\end{abstract}

\section{RIWAYAT ARTIKEL}

Article History

Diterima : 24 Agustus 2019

Dipublikasi : 25 November 2019

\section{KATA KUNCI}

Keywords

Era Disrupsi; Cryptocurrency;

Bitcoin; Legalitas, Hukum, Ekonomi 


\section{PENDAHULUAN}

Era Disrupsi atau yang dikenal sebagai revolusi 4.0 membuat dunia menuju ke arah yang baru di mana mencakup berbagai aspek dalam kehidupan dan salah satu aspek penting adalah dalam bidang ekonomi. Dalam perkembangan di bidang ekonomi di era disrupsi tentu saling bersinergi satu sama lain dengan perkembangan teknologi serta aksesibiltas penegakan hukum. Salah satu perkembangan di bidang ekonomi adalah munculnya metode pembayaran baru dalam transaksi bisnis. Seperti yang kita ketahui bahwa dalam transaksi bisnis biasa menggunakan cara konvensional yaitu menggunakan mata uang konvensional tetapi di era disrupsi ini dalam hal transaksi bisnis bergeser ke arah digitalisasi yaitu menggunakan media internet. Keuntungan menggunakan internet adalah para pembeli dan penjual dalam hal bertransaksi tidak harus bertemu secara langsung dan bisa melakukan transaksi kapan dan dimana saja dengan menggunakan media internet, oleh karena kemudahan dalam bertransaksi pada era ini di tuntut pula metode pembayaran yang mudah, efektif sera efisien untuk digunakan. Salah satu metode pembayaran yang muncul untuk menjawab tuntutan ini adalah Cryptocurrency. Cryptocurrency adalah mata uang digital yang menggunakan sistem enskripsi dan sudah berbagai macam bentuk mata uang digital ini tersebar di dunia. Dalam beberapa dekade beberapa jenis mata uang digital mulai bermunculan seperti Bitcoin, Peercoin, Auroracoin, Litecoin, Ripple, dan Dogecoin, dll. Di antaranya yang paling menarik perhatian masyarakat dunia adalah kehadiran Bitcoin. Bitcoin menjadi fenomena tersendiri di karenakan ada sebuah mata uang yang tidak di kendalikan oleh pihak manapun bahkan pemerintah dan bank. Dalam perkembangannya Bitcoin menarik perhatian beberapa kalangan yang tertarik menggunakan Bitcoin sebagai media pembayaran maupun investasi.

Bitcoin adalah sebuah protokol komunikasi online yang memfasilitasi penggunaan mata uang virtual, Bitcoin didirikan oleh Nakamoto pada tahun 2008 dan telah melayani sekitar 62,5 juta dari sekitar 109 juta akun yang ada. Mulai Maret 2015 volume transaksi Bitcoin dalam sehari saja mencapai 200.000 Bitcoin atau kira kira sekitar \$50 juta dengan menggunakan nilai tukar pasar dan total nilai pasar semua bitcoin yang tersikulasi mencapai \$3.5 Milliar (Böhme dkk,2015). Bitcoin menarik perhatian dunia di karenakan beberapa faktor seperti Bitcoin tidak di kendalikan oleh pihak manapun, mudah untuk digunakan, biaya dalam transaksinya terbilang murah, serta nilainya yang bisa naik dan turun secara drastis membuat Bitcoin menjadi media investasi yang cukup menjanjikan dan sering kali Bitcoin disebut sebagai digital gold. Bitcoin dengan segala keuntungan yang dimiliki dalam sistem penyimpanan maupun transaksinya sangat riskan sekali sebagai media untuk melaukan kejahatan seperti Money Laundry, pendanaan aksi terorisme, jual beli narkoba serta senjata, penipuan, dan berbagai macam kejahatan yang menggunakan media internet. Karena sistem Bitcoin yang sangat 
ketat karena menggunakan algoritma sehingga hanya pemiliknya saja yang bisa mengaksesnya dan sistem transaksi dari Bitcoin sendiri yang bersifat anonymous menyulitkan bagi pihak berwenang untuk melacak arus transaksi yang terjadi. lalu resiko yang ada terkait kehadiran Bitcoin adalah tentang pendanaan aksi terorisme, pada tahun 2015 group peretas yang bernama "Ghost Security Group" mengungkapkan bahwa beberapa akun keuangan jaringan teroris ISIS dalam jaringan transaksi Bitcoin memiliki nominal setara dengan \$4.1 milyar (Anonymous, 2018).

Di Indonesia sendiri Bitcoin belum memiliki kejelasan apakah dianggap sebagai mata uang atau tidak serta belum ada regulasi khusus terkait penggunaannya. Dari pihak Bank Indonesia disarankan untuk berhati-hati dengan Bitcoin dan mata uang virtual lainnya. Semua risiko yang terkait dengan kepemilikan atau penggunaan Bitcoin ditanggung oleh pemilik atau pengguna Bitcoin dan mata uang virtual lainnya. Berdasarkan pernyataan dari BI di atas dapat disimpulkan bahwa pemerintah Indonesia tidak memberikan perlindungan hukum terkait dengan semua risiko yang mungkin terjadi dalam penggunaannya serta bertentangan dengan pasal 28D(1) Undang-Undang Dasar 1945 yang menyatakan bahwa "Setiap orang berhak atas pengakuan, jaminan, perlindungan, dan kepastian hukum yang adil serta perlakuan yang sama dihadapan hukum".

\section{Rumusan Masalah}

1. Apa itu Bitcoin dan bagaimana sistemnya?

2. Bagaimana respon dan regulasi pemerintah terkait dengan peredaran mata uang Bitcoin di Indonesia?

3. Bagaiaman respon dan regulasi pemerintah terkait dengan peredaran mata uang Bitcoin di Indonesia?

\section{Metode Penulisan}

Jenis penelitian yang digunakan dalam penelitian ini adalah penelitian hukum normatif yang berfokus pada perumusan masalah dan hipotesis melalui pengambilan sampel, mengukur variabel, dan mengumpulkan data yang berakhir pada suatu kesimpulan. Kemudian pendekatan penelitian yang digunakan adalah law (pendekatan hukum) yang dilakukan dengan meneliti hukum dan peraturan yang berkaitan dengan masalah hukum yang terkait dengan Bitcoin dan menggunakan pendekatan dengan metode penelitian kualitatif yang bersifat deskriptif dan analisis data yang mendalam.

Sumber dan jenis data yang digunakan dalam penelitian ini adalah sumber data primer dan sumber data sekunder, sumber data primer yang diperoleh dari peraturan dan perundang-undangan hukum dan peraturan hukum terkait lainnya seperti Bank Indonesia dan Otoritas Jasa Keuangan. Sedangkan data sekunder diperoleh dari referensi seperti buku, jurnal, tinjauan pustaka, dokumentasi, 
publikasi, studi penelitian yang ada, dan sumber-sumber dari internet tentang subjek penelitian secara rinci.

\section{PEMBAHASAN}

\section{A. Bitcoin dan cara kerjanya}

Perkembangan teknologi informasi dan komunikasi yang berkembang pesat ini harus ditanggapi dengan hati-hati untuk dapat memberikan manfaat maksimal bagi pertumbuhan ekonomi di Indonesia. Dengan dimulainya era digitalisasi ini dalam hal ekonomi, terutama dalam aspek transaksi bisnis tren baru bermunculan sehingga menggeser cara konvensional dengan menggunakan mata uang kertas dan logam menju ke arah dunia maya atau digital menggunakan mata uang digital yang membuat peluang bisnis semakin menarik dan menjanjikan bagi semua orang. Mata uang digital ini menggunakan sebuah system Cryptography yang cukup kompleks sehingga tidak dapat dipindahkan bagi yang tidak memiliki akses serta tidak dapat diduplikasi jumlahnya, jenis mata uang ini diperkenalkan dengan citra independen yang peredarannya tidak diatur oleh pihak mana pun di dunia bahkan pemerintah atau bank sekalipun, di antara mata uang digital yang tersebar di dunia kehadiran Bitcoin menjadi fenomena tersendiri.

Bitcoin adalah salah satu jenis Cryptocurrency yang terdistribusi dan terdesentralisasi. Pengguna Bitcoin disebut sebagai klien dan masing-masing dari mereka dapat mengatur akun yang dikenal sebagai alamat. Seorang klien dapat mengirim Bitcoin ke klien lain dengan melakukan transaksi dan memasukkannya ke dalam log global dalam bentuk sebuah pembukuan yang besar yang disebut Blockchain. Blockchain dikelola oleh penambang Bitcoin yang akan diberi imbalan atas upaya mereka dalam sistem Bitcoin. Transaksi Bitcoin dilindungi oleh teknik Cryptography yang membuat hanya si pemilik sah alamat (Eyal dkk,2013).

Bitcoin didirikan oleh seseorang atau kelompok yang diketahui sebagai Nakamoto pada tahun 2008 dan telah melayani sekitar 62,5 juta dari sekitar 109 juta akun yang ada. Mulai Maret 2015 volume transaksi Bitcoin dalam satu hari mencapai 200.000 Bitcoin, sekitar $\$ 50$ juta menggunakan nilai tukar pasar dan total nilai pasar semua bitcoin yang diperkirakan mencapai \$3,5 miliar. Bitcoin menarik para pakar ekonomi yang tertarik pada mata uang digital ini karena berpotensi bisa merusak sistem pembayaran yang ada dan akan menyebabkan moneter di masa depan jika Bitcoin berinteraksi dengan sistem ekonomi konvensional dan ekonomi riil (Böhme dkk,2015). Seiring berjalannya waktu, nilai tukar Bitcoin telah meningkat karena banyaknya permintaan yang muncul sebagai media pembayaran berskala global menggunakan sistem jaringan peer-to-peer yang umum digunakan oleh programmer. Bitcoin menggunakan jaringan peer-to-peer atau layanan berbagi file sehingga dapat membagikan Bitcoin di antara sesama pengguna di jaringan komputer. Keuntungan yang ditawarkan dalam Bitcoin adalah kemudahan dan biaya murah. Bagi mereka yang mulai menggunakan Bitcoin, mereka harus 
memiliki apa yang disebut dompet atau disebut virtual wallet, virtual wallet ini terdiri dari 3 jenis, yaitu soft virtual wallet, phone wallet, dan web wallet. Perbedaan antara ketiganya adalah letak dimana Bitcoin itu disimpan, pada web wallet memberikan akses untuk menggunakan Bitcoin di mana saja dengan menggunakan internet tidak jauh berbeda dengan perbankan online dan dengan web wallet juga kita bisa melihat jumlah Bitcoin yang disimpan. Dompet memiliki fungsi yang sama dengan bank konvensional tetapi dalam penggunaan dompet memiliki perbedaan yaitu ketika terjadi kejahatan bukan tanggung jawab bank atau pemerintah (Koeswanto,2017).

Dalam hal distribusi Bitcoin, protokol mengeluarkan sejumlah Bitcoin setiap 12 menit dalam jaringan Bitcoin yang awalnya dikeluarkan adalah 50 dana BTC yang akan dibagi dua setiap 4 tahun. Distribusi Bitcoin menggunakan konsep yang disebut aturan Half-life yaitu bahwa distribusi awal akan berkurang setengah setelah periode waktu tertentu, inilah yang menyebabkan Bitcoin menjadi persediaan terbatas. Karena nilai komoditas yang terus menurun sama dengan emas maka akan berhenti distribusinya jika mencapai 21.000.000 BTC (Anonymous,2017). Ada 2 konsep untuk mendapatkan Bitcoin, cara pertama adalah penambangan Bitcoin. Penambang Bitcoin adalah orang-orang yang menggunakan komputer untuk melakukan perhitungan kalkulasi dan menemukan blok di dalam Blockchain, jika Blockchain telah diverifikasi oleh penambang maka langkah selanjutnya adalah memberikan penghargaan dalam bentuk Bitcoin untuk penambang yang telah memverifikasi. Konsep ini mengambil sedikit referensi dari Hal Finney yang dikembangkan oleh Nick Szabo, sebuah teori untuk memahami sistem pembuktian kerja yang akurat. Dengan perkembangan teknologi yang terjadi, para penambang tidak lagi menggunakan komputer atau laptop melainkan menggunakan alat khusus yang disebut ASIC (Application Specific Integrated Circuit) yang merupakan sirkuit elektronik khusus yang dibuat untuk melakukan perhitungan matematis yang digunakan dalam sistem Bitcoin. Seorang Penambang dapat menghasilkan Bitcoin dengan cara yang lebih efektif dan efisien karena ASIC memiliki lebih banyak kemampuan daripada komputer pada umumnya. Cara kedua yang bisa dilakukan untuk mendapatkan Bitcoin adalah cara konvensional jual beli di situssitus yang menjual Bitcoin, di Indonesia sudah ada 2 tempat pasar besar sebagai tempat untuk membeli dan menjual Bitcoin yaitu Bitx.co/id dan bitcoin. co.id (Yohandi,2017).

\section{B. Hukum di Indonesia terkait dengan peredaran Bitcoin di Indonesia}

Pada era disrupsi ini perkembangan dari segi teknologi informasi dan komunikasi semakin berkembang. Muncul berbagai macam jenis inovasi-inovasi baru bermunculan, oleh karena perkembangan yang pesat ini harus di ikuti pula perkembangan dalam sektor hukum. Penegakan hukum harus bisa mengikuti perkembangan yang ada serta menjawab tantangan baru yang muncul terkait dengan perlindungan hukum dalam hal teknologi. Seperti yang kita ketahui 
kehadiran Bitcoin sebagai bentuk alat pembayaran global tidak hanya menjadi fenomena di dunia sehingga sering kali menimbulkan pro dan kontra antara dua sisi, para pengguna Bitcoin mengatakan bahwa Bitcoin adalah mata uang masa depan dan mereka yang menentang mempertimbangkan bahwa Bitcoin itu sendiri bukan pembayaran yang legal dan tidak dapat dikatakan sebagai sebuah mata uang yang sah. Kehadiran Bitcoin di Indonesia menyebabkan masalah sendiri karena sistem Bitcoin sendiri masih dipertanyakan dan masih ditinjau dari segi penggunaannya, berdasarkan wawancara dengan CEO PT Bitcoin Indonesia Oscar Darmawan, mengatakan " Sistem Bitcoin memiliki sistem pencatatan bersama dalam transaksi yang disebut Blockchain yang dapat digunakan sebagai referensi jika ada kejahatan dalam penggunaan Bitcoin itu sendiri" (Yohandi, 2017). Bertentangan dengan pernyataan CEO PT Bitcoin Indonesia, Bank Indonesia memberikan informasi lebih lanjut melalui Deputi Gubernur Bank Indonesia (BI) Ronald Waas, menyampaikan bahwa Bank Indonesia memiliki peraturan tentang mata uang, dalam Undang-Undang No. 7 tahun 2011 tentang Mata Uang dan Hukum 23 tahun 1999 tentang Bank Indonesia sebagaimana telah diubah dengan Undang-Undang Nomor 6 Tahun 2009 tentang Bank Indonesia. Bahwa "Mata uang yang berlaku di wilayah NKRI adalah Rupiah".

Eni V. Panggabean, Kepala Departemen Kebijakan dan Pemantauan Sistem Pembayaran Bank Indonesia menambahkan, "Bank Indonesia melarang penggunaan mata uang virtual dalam model atau jenis apa pun dan merek apa pun". Selanjutnya dari konfirmasi yang disampaikan oleh Bank Indonesia dalam Pasal 34 huruf a Peraturan Bank Indonesia Nomor 18/40 / PBI / 2016 tentang Pelaksanaan Pemrosesan Transaksi Pembayaran (Peraturan BI 18/2016) dijelaskan bahwa terkait dengan Mata Uang Virtual adalah ' 'Uang digital dikeluarkan oleh otoritas moneter yang diperoleh dengan menambang, membeli, atau mentransfer hadiah termasuk Bitcoin, BlackCoin, Dash, Dogecoin, Litecoin, Namecoin, Nxt, Peercoin, Primecoin, Ripple, dan Ven tidak termasuk dalam pemahaman Mata Uang Virtual". Dari pernyataan yang disampaikan oleh BI bahwa pihaknya mendesak masyarakat untuk lebih berhati-hati dalam penggunaan Bitcoin dan semua risiko yang terjadi adalah tanggung jawab pengguna atau pemilik. Jika kita menilai dari regulasi dan hukum yang sudah ada di Indonesia terkait dengan penggunaan Bitcoin:

\section{A. Undang-Undang Nomor 7 Tahun 2011:}

Dalam ulasan UU No. 7 tahun 2011 tentang Mata Uang jika kita melihat dalam undang-undang tentang mata uang menurut pasal 1 paragraf 2 UU No. 7 tahun 2011 "mata uang adalah alat pembayaran yang sah dan uang yang dikeluarkan oleh Republik Indonesia, selanjutnya disebut rupiah". Jika kita melihat definisi Bank Indonesia peraturan dan undang-undang bahwa uang adalah instrumen pembayaran yang sah yang dikeluarkan oleh pemerintah dan pihak berwenang, maka dalam pasal 21 dan pasal 22 Undang-Undang Republik Indonesia No. 7 Tahun 2011 tentang Mata Uang yang harus digunakan dalam setiap lalu lintas pembayaran adalah Rupiah. Transaksi perdagangan internasional, deposito bank 
dalam mata uang asing, transaksi pembiayaan internasional harus menggunakan Rupiah. Rupiah sebagai salah satu jenis mata uang yang diakui secara hukum memiliki kriteria khusus dapat dikatakan sebagai mata uang, yaitu:

1. Mudah di bawa, uang harus mudah dibawa ke mana saja yang berarti uang harus digunakan di mana saja. Jenis ini memberikan kenyamanan dan keamanan bagi pemegang uang karena dapat disimpan di tempat tertentu, selain mudah dibawa uang juga bisa menjadi toggle untuk membentuk bezit.

2. Durable (Daya Tahan), uang harus tahan lama karena uang sebagai alat transaksi sering berpindah kepemilikan sehingga bisa terjadi kerusakan oleh karena itu uang dituntut untuk memiliki sifat tahan lama untuk mencegah nilai uang berkurang karena kerusakan fisik yang terjadi

3. Dapat Dibagi menjadi unit yang lebih kecil, uang harus bisa dipecah menjadi nilai yang lebih kecil untuk digunakan dalam transaksi dengan nilai yang lebih kecil

4. Dapat distandarisasi, dapat dibakukan dengan orang-orang akan menggunakan uang tanpa keraguan kualitas uang, uang yang dicetak memiliki standar tersendiri yang sudah di atur dalam hukum

5. Diakui, salah satu syarat yang harus dipenuhi adalah pengakuan, persyaratan ini penting karena pengakuan memberikan perbedaan antara barang berharga atau barang yang tidak layak

6. Nilainya stabil (stabilitas nilai), manfaat dari sesuatu yang membuat uang memiliki nilai dan nilai uang ini perlu tetap stabil, stabil tidak berarti memiliki nilai tetap tetapi tidak berfluktuasi tajam karena nilainya tidak stabil dan fluktuasi pertumbuhan nilainya tidak terlalu tajam perubahannya.

7. Jumlahnya cukup (elastisitas penawaran), jumlah uang yang beredar harus memenuhi kebutuhan ekonomi, ketika uang tidak cukup itu akan menghambat perkembangan dunia oleh karena itumata uang harus dapat melihat kondisi perekonomian (Haryono, 2017).

Jika kita melihat dalam Undang-undang di atas, dapat dikatakan bahwa

Bitcoin tidak sama dengan kriteria mata uang dan dapat dikatakan sebagai mata uang, Bitcoin tidak memenuhi syarat dalam:

a) Persyaratan pertama tidak terpenuhi Bitcoin adalah karena Bitcoin tidak dapat distandarisasi, karena Bitcoin terbuka tanpa adanya kontrol dalam hal sirkulasi dan distribusi pihak mana pun dan meskipun pemerintah dan juga bank. Bitcoin dijalankan menggunakan program komputer yang membuatnya tidak mungkin untuk distandarisasi.

b) Persyaratan kedua yang tidak memenuhi adalah pengakuan. Mengakui dengan artian bahwa mata uang tersebut diperoleh dari otoritas yang berwenang di suatu negara dalam sistem pembayaran di Indonesia, dan dalam penagkuan juga tidak boleh bertentangan dengan hukum yang menyatakan bahwa mata uang yang legal digunakan dan yang diakui adalah Rupiah. Rupiah memiliki kekuatan sebagai mata uang karena dikeluarkan 
dan dikelola oleh otoritas yang berwenang berbeda dari pencipta Bitcoin yang masih belum jelas identitasnya

c) Persyaratan ketiga Bitcoin tidak terpenuhi adalah nilai yang stabil. Seperti yang kita ketahui bahwa nilai Bitcoin berfluktuasi secara tajam yang bisa naik turun tergantung dari permintaan dan dapat dikatakan bahwa Bitcoin nilainya tidak stabil

d) Persyaratan keempat Bitcoin tidak terpenuhi adalah jumlah yang dapat dipenuhi. Bitcoin yang beredar mengalami batasan bahwa jumlah Bitcoin yang beredar di masyarakat tidak terlalu banyak untuk mempertahankan nilai Bitcoin itu sendiri. Oleh karena itu Bitcoin tidak memenuhi sebagai mata uang karena mata uang jumlahnya harus bisa mencukupi.

\section{B. Undang-Undang Nomor 11 Tahun 2008:}

Dalam ulasan UU No. 11 tahun 2008 tentang Informasi dan Transaksi Elektronik jika kita melihat Undang-Undang Nomor 11 tahun 2008 tentang Informasi dan Transaksi Elektronik Pasal 5 paragraf 3 menyatakan "Informasi Elektronik dan / atau Catatan Elektronik dinyatakan sah ketika menggunakan Sistem Elektronik mengikuti ketentuan yang diatur dalam Undang-Undang ini”. Dalam Undangundang ini kemudian menetapkan persyaratan minimum sistem elektronik yang beroperasi di Indonesia, yaitu:

a) Dapat menampilkan kembali Informasi Elektronik dan / atau dokumen elektronik sepenuhnya sesuai dengan periode penyimpanan yang bertanggung jawab atas undang-undang.

b) Dapat melindungi ketersediaan, integritas, keaslian, kerahasiaan, dan aksesibilitas Informasi Elektronik dalam penerapan sistem elektronik

c) Dapat beroperasi mengikuti prosedur atau penunjuk dalam implementasi elektronik.

d) Dilengkapi dengan prosedur atau instruksi yang diumumkan dengan bahasa, informasi, atau simbol yang dapat dipahami oleh pihak-pihak yang terkait dengan implementasi sistem elektronik, dane)

e) Memiliki mekanisme berkelanjutan untuk menjaga kebaruan, kejelasan dan prosedur respon atau tanggung jawab pengguna

Mata uang virtual yang digunakan sebagai media pertukaran dan alat pembayaran bahkan menjadi media investasi yang menguntungkan bagi beberapa pihak yang menggunakan sistem transaksi Bitcoin menggunakan media internet tidak luput dari siklus regulasi terkait perdagangan elektronik yang dilakukan dengan menggunakan Internet melalui komputer jaringan. Dalam perdagangan elektronik masih harus memiliki lisensi yang sama dengan perdagangan konvensional, untuk lisensi bisnis dan memenuhi persyaratan. Dalam UndangUndang No. 7 tahun 2011 tentang mata uang terlihat jelas bahwa Bitcoin tidak diakui sebagai alat pembayaran yang sah dan jika tentang Undang-Undang No. 11 tahun 2008 tentang Informasi dan transaksi Elektronik maka dapat dikatakan bahwa Bitcoin memenuhi syarat sebagai sistem transaksi elektronik. 
Karena kurangnya regulasi terutama terkait dengan keamanan, perlindungan dan kepastian hukum dari upaya pemerintah dalam hal gangguan potensial yang terkait dengan transaksi elektronik, pemerintah membuat undangundang baru dengan memberlakukan UU No. 19 tahun 2016 tentang ITE yang merupakan peningkatan dari UU No. 11 tahun 2008 tentang ITE adalah upaya pemerintah untuk menangani semua masalah keamanan yang terkait dengan transaksi elektronik sehingga pemanfaatan di bidang transaksi elektronik tumbuh secara optimal. Ini tidak berarti bahwa masalah yang ada mengenai mata uang virtual dengan produk akhir mereka dari undang-undang ini karena belum ada kejelasan tentang diizinkan atau tidak terkait dengan penggunaan Bitcoin di Indonesia.

\section{Pasal 28 UUD 1945}

Dalam ulasan Pasal 28 UUD 1945 di Indonesia, sikap pemerintah sebagai negara yang demokratis dan berdaulat harus dapat menjamin bahwa masyarakat dapat menggunakan teknologi yang ada demi memajukan bangsa yang termaksud dalam UUD 1945 pasal 28C pasal 1 dan 2 UU 1945, yaitu:

1. Setiap orang memiliki hak untuk mengembangkan diri melalui pemenuhan kebutuhan dasar, berhak atas pendidikan dan mendapatkan manfaat dari ilmu pengetahuan dan teknologi, seni dan budaya, untuk meningkatkan kualitas hidupnya dan demi kesejahteraan umat manusia

2. Setiap orang memiliki hak untuk memajukan dirinya sendiri dalam memperjuangkan hak-hak mereka secara kolektif untuk mendukung membangunkan masyarakat, bangsa, dan negara. Terkait dengan kepastian hukum juga diatur dalam Pasal 28D, yaitu: Setiap orang memiliki hak untuk pengakuan, keamanan, perlindungan dan kepastian hukum dan perlakuan yang sama di hadapan hukum

Sudah jelas bahwa dalam kasus penggunaan Bitcoin harus ada sikap tegas dari pemerintah untuk memberikan kepastian hukum tetapi sampai sekarang pemerintah belum menentukan langkah-langkah dan merumuskan kebijakan tertulis terkait dengan pesanan dan pengawasan? Kemudian muncul pertanyaan tentang bagaimana perlindungan hukum terhadap pengguna Bitcoin rentan terhadap potensi kejahatan yang dilakukan karena Bitcoin masih baru di Indonesia.

\section{Hukum di Indonesia terkait dengan peredaran Bitcoin di Indonesia}

Bitcoin sejak kemunculannya pada tahun 2009 sebagai metode pembayaran baru dalam skala global telah menjadi fenomena bagi negara. Dengan sistem yang tidak dikendalikan oleh pihak mana pun termasuk bank atau pemerintah suatu negara. Ada dua sikap jelas yang diambil oleh suatu negara yaitu ada dua pendapat antara negara yang menerima dan menerapkan aturan dan menolak. Negaranegara yang menerima Bitcoin secara terbuka adalah Amerika Serikat, Kanada, Australia, Finlandia, Jerman, dll dan negara-negara yang sangat menolak adalah China, Rusia, Vietnam, Bangladesh, dll.Sedangkan di Indonesia masih belum ada 
kejelasan apakah Bitcoin boleh digunakan atau tidak serta regulasi hukum dalah hal perlindungannya, beda halnya dengan berbagai negara yang sudah mengambil sikap terkait dengan Bitcoin serta menerapkan regulasi hukum terkait dengan perlindungan hukum yang bisa menjadi contoh bagi Indonesia dalam menentukan langkah kedepan terkait dengan hadirnya mata uang digital sebagai suatu system baru dalam skala global.

Negara yang mengakui serta sudah menetapkan regulasi hukumnya adalah negara adikuasa yaitu Amerika Serikat yang secara terbuka positif tentang keberadaan Bitcoin meskipun beberapa lembaga negara tersebut berusaha mengurangi penggunaannya. Perusahaan-perusahaan terkenal seperti Dish Network (DISH), Microsoft Store, pengecer sandwich, Subway, dan Overstock.com (OSTK) menerima pembayaran dalam bentuk Bitcoin. tentang Bitcoin sejak 2013, Departemen Keuangan Amerika Serikat telah mendefinisikan Bitcoin bukan sebagai mata uang, tetapi sebagai bisnis layanan uang (MSB). Ini menempatkannya di bawah Undang-Undang Kerahasiaan Bank yang mewajibkan pertukaran dan pemrosesan pembayaran untuk memenuhi tanggung jawab tertentu seperti pelaporan, pendaftaran, dan penyimpanan catatan. Juga, Bitcoin dikategorikan sebagai properti untuk keperluan pajak oleh Internal Revenue Service (IRS).

Sama halnya dengan Amerika, negara tetangganya Kanada juga bersikap positif tentang keberadaan Bitcoin tetapi dengan kebijakan yang berbeda. Meskipun diterima secara positif, Kanada masih berhati-hati agar kejahatan dalam penggunaan Bitcoin dapat terjadi. Menurut Canadian Revenue Agency (CRA), Bitcoin dipandang sebagai bentuk barter transaksi dan pendapatan yang dihasilkan dianggap pendapatan bisnis di bawah lingkup Undang-Undang Anti Pencucian Uang (AML) dan dalam pertukaran Bitcoin perlu mendaftar dengan keuangan. pusat transaksi dan analisis Kanada melaporkan (FINTRAC) termasuk melaporkan transaksi yang mencurigakan, mematuhi kepatuhan, dan menyimpan catatan tertentu. Sikap Bank di Kanada secara tegas melarang penggunaan kredit atau debit mereka untuk transaksi Bitcoin (Bajpai, 2016). Sementara itu di Singapura bitcoin dapat beredar tetapi bank sentral tidak mengganggu transaksi dengan bitcoin, tetapi akan mengenakan pajak karena bitcoin dianggap sebagai komoditas, di Malaysia bank sentral mengizinkan transaksi dengan bitcoin, tetapi masyarakat didorong untuk berhati-hati dalam membuat transaksi dan berinvestasi dengan mata mereka uang virtual ini.

Jika ada negara yang menerima Bitcoin dan menerapkan peraturan peredarannya, akan ada negara yang melarang penggunaan Bitcoin di negaranya. Bank sentral Islandia menyatakan bahwa transaksi dengan bitcoin dianggap sebagai pergerakan modal keluar dan ilegal, bank sentral Rusia memperingatkan bisnis yang menggunakan bitcoin sebagai alat pembayaran dengan potensi keterlibatan dalam pencucian uang atau pendanaan terorisme (Koeswanto, 2017). Negara China baru-baru ini mengeluarkan peraturan tentang langkah-langkah untuk 
mencegah penggunaan mata uang digital di negara itu. Perkembangan terbaru ini dapat menghilangkan perdagangan Cryptocurrency dan kegiatan Penambangan di Cina. Otoritas negara Tiongkok memberlakukan larangan pasokan koin awal (ICO), larangan tersebut membuat penurunan sekitar $6 \%$ pada saat harga Bitcoin pada saat itu dan membuat pertukaran Bitcoin BTC yang berbasis di Shanghai dipaksa untuk menutup operasi perdagangannya, PBOC dan melarang lembaga keuangan berbasis di Cina dari semua transaksi dan pendanaan dalam kegiatan yang terkait dengan mata uang digital. PBOC memandang mata uang virtual adalah ilegal, karena mereka tidak dikeluarkan oleh lembaga moneter yang diakui dan tidak memiliki aturan hukum yang jelas (Sheet, 2015).

\section{KESIMPULAN}

Dalam peredarannya sebagai sebuah metode transaksi dalam sektor ekonomi, Bitcoin menjadi fenomena tersendiri di berbagai belahan dunia. Beberapa negara memutuskan bersikap terbuka serta menerapkan aturan sedemikian rupa terkait dengan penggunaan Bitcoin dan juga negara yang secara tegas menolak peredaran Bitcoin dikarenakan memiliki potensi kejahatan serta tidak memenuhi kriteria dapat dikatakan sebagai mata uang. Di Indonesia sendiri belum adanya kejelasan terkait dengan boleh atau tidaknya penggunaan mata uang Bitcoin dalam hal transaksi di Indoneisa serta regulasi hokum yang belum jelas. Berdasarkan penjelasan diatas dapat disimpulkan bahwa jenis mata uang virtual yaitu Bitcoin dan sejenisnya:

1. Penggunaan mata uang Bitcoin dalam skala global, termasuk Indonesia, telah mengalami peningkatan yang signifikan dalam hal penggunaannya sebagai alat pembayaran dalam transaksi dan media investasi, meskipun kehadiran Bitcoin masih belum mendapat pengakuan resmi dari pemerintah apakah Bitcoin dapat digunakan atau jika Bitcoin. Dan dalam ulasan UU No. 7 tahun 2011 tentang mata uang, dikatakan bahwa Bitcoin bukan tender hukum tetapi jika kita lihat dalam UU No. 11 tahun 2008 tentang Informasi dan transaksi elektronik menjelaskan bahwa Bitcoin termasuk persyaratan karena semua sistem transaksi elektronik. Kemudian muncul pertanyaan tentang bagaimana bentuk pengawasan pemerintah terkait dengan meningkatnya sirkulasi peredaran Bitcoin, sikap pemerintah terkait dengan legalitas Bitcoin di Indonesia, serta bentuk kontrol pemerintah terhadap penyedia layanan perdagangan Bitcoin di Indonesia

2. Berbagai negara sudah mengambil langkah terkait dengan legalitas Bitcoin itu boleh digunakan atau tidak sebagai suatu mata uang serta regulasi hukum dalam peredarannya yang bisa menjadi tolak ukur langkah pemerintah kedepannya terkait dengan peredaran mata uang virtual.

3. Adanya kendala hukum pemerintah dalam menerapkan perlindungan hukum secara keseluruhan adalah karena tidak adanya undang-undang yang 
mengatur penggunaan mata uang virtual transaksi Bitcoin dan media investasi yang dihasilkan ketika sekitar seorang pria mendapatkan kerugian akibat penggunaan Bitcoin tidak dapat mengajukan perkara karena hukum pengaturannya saja tidak ada.Sikap pemerintah yang berkontradiksi dengan pasal 28G Undang-Undang Dasar 1945 bahwa setiap orang memiliki hak untuk pengakuan, keamanan, perlindungan, dan kepastian hukum dan perlakuan yang sama di hadapan hukum dan pemerintah Indonesia tidak dapat memenuhi prinsip tanggung jawab untuk melindungi (tanggung jawab untuk melindungi prinsip) sebagai negara merdeka dan berdaulat.

Saran bagi pemerintah Indonesia untuk kehadiran Bitcoin di Indonesia yang terus meningkat penggunanya dari waktu ke waktu adalah:

1. Dengan harapan pemerintah membuat regulasi terkait secara khusus dengan keberadaan mata uang virtual sehingga posisinya tidak menjadi samarsamar (grey area) di karena di satu sisi memiliki potensi yang memungkinkan untuk meningkatkan potensi ekonomi bangsa, tetapi di satu sisi memiliki potensi kejahatan yang dapat terjadi jika tidak ada langkah tegas dari pihak pemerintah Indonesia sebagai negara demokrasi yang berdaulat untuk memberikan perlindungan kepada rakyat Indonesia.

2. Selain membuat peraturan peraturan, pemerintah harus membentuk lembaga ahli khusus memahami rincian Bitcoin untuk mencegah tindakan kriminal yang dapat terjadi bekerja sama dengan Bank Indonesia dan Otoritas Jasa Keuangan dalam mengawasi sirkulasi Bitcoin di Indonesia.

3. Bagi orang-orang yang sudah mulai dan akan mulai menggunakan Bitcoin untuk lebih berhati-hati dalam penggunaannya sebagai alat pembayaran serta media karena semua risiko investasi dalam penggunaannya dalam biaya kepada pengguna. 


\section{DAFTAR PUSTAKA}

\section{Peraturan dan Perundang - Undangan}

Pasal 28 Undang-Undang Dasar 1945

Peraturan Bank Indonesia No.18/40/PBI/2016 terkait dengan system pembayaran Undang-undang Nomor 11 Tahun 2008 tentang informasi dan transaksi elektronik Undang-undang Nomor 7 Tahun 2011 tentang mata uang

\section{Jurnal dan Disertasi}

Eyal Itty \& Gun Emin Sirer, "Majority Is Not Enough: Bitcoin Mining Is Vulnerable", Department Of Computer Science, Cornell University, 2013, hlm.3

Haryono Aby, " Analysis of the Juridical Bitcoin According to the Regulation Legislation in Indonesia ", Faculty of Law, University of Indonesia ", 2014, hlm.8-9

Rainer, Böhme dkk.2015. "Bitcoin: Economics, Technology, and Governance". Jurnal Ekonomi Vol 29,No 2 tahun 2015.32

Sakti Eka Koeswanto \& Taufik Muhammad, "Protection of Investors Investing Virtual Currency", Living Law Journal, 9 (1), 2017

Yohandi Axel, 'Implikasi Yuridis Penggunaan Mata Uang Virtual itcoin Sebagai Alat Pembayaran Dalam Transaksi Komersial (Studi Komparasi Antara Indonesia-Singapura)", Diponegoro Law Journal, 6(2), 2017, hlm.3

\section{Artikel Online}

Anonymous.2018. "BI: Bitcoin Bisa Jadi Alat Pendanaan Terorisme". https://economy.okezone.com/read/2018/01/24/20/1849544/bi-bitcoinbisa- jadi-alat-pendanaan-terorisme, (Di akses pada 18 September, 22.23)

Bajpai Prableen , "Countries Where Bitcoin Is Legal \& Illegal (DISH, OTSK)" https://www.investopedia.com/articles/forex/041515/countries-wherebitcoin-legal-illegal.asp, (Di akses pada 18 September 2019, 17.09)

Sheet Shobhit, "Is Bitcoin Banned In China", https://www.investopedia.com/news/bitcoin-banned-china/, (Di akses pada 19 September, 19.20) 


\section{Judex Set Lex}

\section{Laguens}

\section{Sang Hakim adalah Hukum yang Berbicara}

